\title{
KONSEP DASAR DAN ETIKA FILSAFAT PENDIDIKAN ISLAM
}

\author{
Muhammad Dahri ${ }^{1}$, Mufli ${ }^{2}$,
}

Dosen Pembimbing: Ibnu Hajar Sainuddin ${ }^{3}$

\author{
${ }^{1}$ Sekolah Tinggi Agama Islam (STAI) Darul Dakwah Wal-Irsyad (DDI) Kota \\ Makassar, Indonesia \\ Email: dahrii.kk@gmail.com \\ ${ }^{2}$ Sekolah Tinggi Agama Islam (STAI) Darul Dakwah Wal-Irsyad (DDI) Kota \\ Makassar, Indonesia \\ Email: makassardeng074@gmail.com \\ ${ }^{3}$ Sekolah Tinggi Agama Islam (STAI) Darul Dakwah Wal-Irsyad (DDI) Kota \\ Makassar, Indonesia \\ Email: Ibnuhajar@staiddimakassar.ac.id
}

\begin{abstract}
Abstrak
Sebagai Disiplin Ilmu Filsafat, Filsafat Pendidikan Islam mempunyai sumber-sumber dasar pijakan yang dijadikan rujukan operasional disiplinnya. Filsafat pendidikan ini adalah dalam lingkup Islam, maka sudah barang tentu ia mengikuti ajaran islam dalam pembahasan masalahmasalahnya. Ajaran dan pendidikan islam itu sendiri bersumber pada al-Qur'an dan al-Hadis, maka kita pada pembahasan ini akan mendapati definisi, ruang lingkup, fungsi, metode dalam filsafat Pendidikan islam dan etika filsafat Pendidikan.
\end{abstract}

\section{Kata Kunci: Filsafat,Konsep Dasar Pendidikan, Filsafat Pendidikan,Etika Dalam berfilsafat}

\section{PENDAHULUAN}

Salah satu unsur pembangun peradaban bangsa adalah melalui pendidikan. Sedangkan hasil akhir sebuah pendidikan tergantung pada tujuan awal pendidikan itu sendiri. Islam dan Barat memiliki pandangan berbeda mengenai hal tersebut. Paham rasionalisme yang berkembang di Barat dijadikan dasar pijakan bagi konsep-konsep pendidikan Barat. Ini jauh berbeda dengan Islam yang memiliki al-Qur'an, Sunnah, dan Ijtihad para ulama sebagai konsep pendidikannya. Hal inilah yang membedakan ciri-ciri dari pendidikan yang ada di Barat dengan pendidikan Islam. Masing-masing peradaban ini memiliki karakter yang berbeda sehingga produk yang 'dihasilkan’ pun memiliki ciri-ciri yang berbeda. 


\section{PEMBAHASAN}

\section{A. Pengertian Filsafat Pendidikan Islam}

Filsafat Pendidikan Islam mengandung tiga komponen kata, yaitu filsafat, pendidikan dan Islam. Untuk memahami pengertian Filsafat Pendidikan Islam akan lebih baik jika dimulai dari memahami makna masing-masing komponen kata untuk selanjutnya secara menyeluruh dari keterpaduan ketiga kata tadi dengan kerangka pikir sebagai berikut: Secara etimologis filsafat berasal dari Bahasa Yunani yaitu kata philein (mencintai) atau philia (cinta) atau philos (sahabat, kekasih) dan sophia (kebijaksanaan, kearifan).

Sedangkan secara terminiologis kata filsafat dalam Kamus Besar Bahasa Indonesia berarti pengetahuan dan penyelidikan dengan akal budi mengenai hakikat segala yang ada, sebab, asal dan hukumnya. ${ }^{1}$ Sementara itu, falsafah berarti anggapan, gagasan dan sikap batin yang paling dasar yang dimiliki oleh orang atau masyarakat. ${ }^{2}$

Menurut pandangan para ahli filsafat diartikan sebagai:

1) Plato (427SM - 347SM) seorang filsuf Yunani yang termasyhur murid Socrates dan guru Aristoteles, mengatakan: filsafat adalah pengetahuan tentang segala yang ada (ilmu pengetahuan yang berminat mencapai kebenaran yang asli).

2) Aristoteles (384 SM - 322SM) mengatakan filsafat adalah ilmu pengetahuan yang meliputi kebenaran, yang di dalamnya terkandung ilmu-ilmu metafisika, logika, retorika, etika, ekonomi, politik, dan estetika (filsafat menyelidiki sebab danasas segala benda).

3) Al-Farabi (meninggal 950M), filsuf Muslim terbesar sebelum Ibnu Sina, mengatakan bahwa filsafat adalah ilmu pengetahuan tentang alam maujud dan bertujuan menyelidiki hakikat yang sebenarnya.

4) Immanuel Kant (1724 -1804), yang sering disebut raksasa piker Barat, mengatakan bahwa filsafat itu ilmu pokok dan pangkal segala pengetahuan yang mencakup di dalamnya empat persoalan, yaitu: "apakah yang dapat kita ketahui? (dijawab oleh metafisika); "apakah yang dapat kita kerjakan? (dijawab oleh etika); "sampai di manakah pengharapan kita? (dijawaboleh antropologi).

Selanjutnya secara etimologis kata pendidikan bersal dari bahasa Yunani yaitu "pedagogi". Kata "Pedagogi", berasal dari kata "paid" yang artinya anak dan "agogos" yang artinya membimbing. Itulah sebabnya istilah pedagogi dapat diartikan sebagai "ilmu dan seni mengajar anak (the art and science of teaching children). Pada Bahasa Romawi, pendidikan berasal dari kata "educare", yaitu mengeluarkan dan menuntun, tindakan, merealisasikan potensi anak yang dibawa waktu dilahirkan di dunia. ${ }^{3}$

Fadhil Al-Jamali memberikan pengertian pendidikan sebagai upaya mengembangkan, mendorong, serta mengajak manusia untk lebih maju dengan berlandaskan nilainilai yang

\footnotetext{
${ }^{1}$ Depatermen Pendidikan Nasional, Kamus Besar Bahasa Indonesia Pusat Bahasa, (Jakarta: PT. Gramedia Pustaka Utama, 2013), h. 392.

${ }^{2}$ Ibid., h. 387.

${ }^{3}$ Hidayat, Rahmat \& Nasution, H.S. (2016) Filsafat Pendidikan Islam Membangun Konsep Dasar Pendidikan Islam. Medan :LPPPI Hal.4
} 
tinggi dan kehidupan yang mulia, sehingga terbentuk pribadi yang lebih sempurna, baik yang berkaitan dengan akal, perasaan, maupun perbuatan. ${ }^{4}$

Sedangkan Ahmad D. Marimba mengemukakan bahwa pendidikan adalah bimbingan atau pemimpin secara sadar oleh pendidik terhadap perkembangan jasmani dan rohani peserta didik menuju terbentuknya kepribadiannya yang utama (insan kamil). ${ }^{5}$ Dilain pihak Ahmad Tafsir mendefinisikan Pendidikan sebagai bimbingan yang diberikan oleh seseorang agar ia berkembang secara maksimal sesuai dengan ajaran islam. ${ }^{6}$

Selanjutnya kata Islam secara etimologi berasal dari Bahasa Arab "aslama-yuslimuislaman" yang secara kebahasaan berarti "menyelamatkan", misal teks "assalamu alaikum" yang berarti "semoga keselamatan menyertai kalian semuanya". Islam atau Islaman adalah masdar (kata benda) sebagai bahasa penunjuk dari fi'il (kata kerja), yaitu "aslama" bermakna telah selamat (kala lampau) dan "yuslimu" bermakna "menyelamatkan" (past continuous tense).

Menurut Muhammad bin Ibrahim bin Abdullah at-Tawairjiri, agama Islam adalah penyerahan diri sepenuhnya kepada Allah dengan mengesakan-Nya dan melaksanakan syariatNya dengan penuh ketaatan atau melepaskan dari kesyirikan.

Setelah memaparkan begitu luas mengenai makna dibalik kata filsafat, pendidikan dan Islam Untuk selanjutnya akan diungkap bagaimana pandangan para ahli mengenai pengertian filsafat pendidikan Islam.

Omar Mohamad al-Toumy al-Syaibany menyatakan bahwa filsafat pendidikan Islam tidak lain ialah pelaksanaan pandangan filsafat dan kaidah filsafat dalam bidang pendidikan yang didasarkan pada ajaran Islam. $^{7}$ Disisi lain Zuhairini menjelaskan bahwa Filsafat Pendidikan Islam adalah studi tentang pandangan filosofis dan sistem dan aliran filsafat dalam Islam terhadap masalah-masalah kependidikan dan bagaimana pengaruhnya terhadap pertumbuhan dan perkembangan manusia muslim dan umat Islam. Selain itu Filsafat Pendidikan Islam mereka artikan pula sebagai penggunaan dan penerapan metode dan system filsafat Islam dalam memecahkan problematika pendidikan umat Islam yang selanjutnya memberikan arah dan tujuan yang jelas terhadap pelaksanaan pendidikan umat Islam. ${ }^{8}$

Sedangkan Abuddin Nata mendefinisikan Filsafat Pendidikan Islam sebagai suatu kajian filosofis mengenai berbagai masalah yang terdapat dalam kegiatan pendidikan yang didasarkan pada Alquran dan al-Hadis sebagai sumber primer, dan pendapat para ahli khususnya filosof muslim sebagai sumbersekunder. Selain itu, Filsafat Pendidikan Islam dikatakan Abuddin Nata suatu upaya menggunakan jasa filosofis, yakni berfikir secara mendalam, sistematik, radikal dan universal tentang masalah-masalah pendidikan, seperti masalah manusia (anak didik), guru, kurikulum, metode dan lingkungan dengan menggunakan Alquran dan al-Hadis sebagai dasar acuannya. ${ }^{9}$

\footnotetext{
${ }^{4}$ Muhammad Fadhil Al-Jamaly, Nahwa Tarbiyat Mukminat, (al-syirkat al-Tunisiyat li al-Tauzi", 1977), h. 3

${ }^{5}$ Ahmad D. Marimba, Pengantar Filsafat Pendidikan Islam, (Bandung AlMa"arif 1989), h. 19

${ }^{6}$ Ahmad Tafsir, Ilmu Pendidikan dalam Perspektif Islam, (Bandung: Ramaja Rosdakarya, 1992), h. 32

${ }^{7}$ Omar Mohammad al-Toumy al-Syaibany, Falsafah Pendidikan Islam, terj. Hasan Langgulung dari Falsafah alTarbiyah al-Islamiyah, (Jakarta: Bulan Bintang, 1979), h. 1.

8 Zuhairini, Filsafat Pendidikan Islam, (Jakarta: Bumi Aksara, 2008), h. 5.

${ }^{9}$ Abudin Nata, Filsafat Pendidikan Islam (Jakarta: Gaya Media Pratama, 2005), h. 15-16.
} 


\section{B. Ruang Lingkup Filsafat Pendidikan Islam}

Dalam hubungan dengan ruang lingkup filsafat Pendidikan Islam ini, Muzayyin Arifin dalam Abudin Nata mengatakan bahwa ruang lingkup pemikirannya bukanlah mengenai halhal yang bersifat teknis operasional pendidikan, melainkan segala hal yang mendasari serta mewarnai corak sistem pemikiran yang disebut filsafat itu. Dengan demikian, secara umum ruang lingkup pembahasan filsafat pendidikan Islam ini adalah pemikiran yang serba mendalam, mendasar, sistematis, terpadu, logis, menyeluruh dan universal mengenai konsepkonsep tersebut mulai dari perumusan tujuan pendidikan, kurikulum, guru, metode, lingkungan, dan seterusnya. ${ }^{10}$

Selanjutnya Jalaludin dan Usman Said menjelaskan bahwa secara makro, apa yang menjadi objek filsafat yaitu ruang lingkup yang menjangkau permasalahan kehidupan manusia, alam semesta dan manusia merupakan objek pemikiran filsafat pendidikan. Secara mikro yang menjadi objek pemikiran atau ruang lingkup filsafat pendidikan sebagai berikut :

- Merumuskan secara tegas sifat hakikat pendidikan;

- Merumuskan sifat hakikat manusia, sebagai subjek dan objek pendidikan;

- Merumuskan secara tegas hubungan antara filsafat, filsafat pendidikan, agama dan kebudayaaan;

- Merumuskan hubungan antara filsafat, filsafat pendidikan, dan teori pendidikan;

- Merumuskan hubungan antara filsafat Negara, filsafat pendidikan, dan politik pendidikan;

- Merumuskan sistem nilai-norma atau isi moral Pendidikan yang merupakan tujuan pendidikan. ${ }^{11}$

Dengan demikian ruang lingkup filsafat pendidikan Islam adalah masalah-masalah yang terdapat dalam kegiatan Pendidikan Islam, seperti msalah tujuan pendidikan Islam, masalah guru, kurikulum, metode dan lingkungan. Secara umum ruang lingkup pembahasan filsafat pendidikan Islam ini adalah pemikiran yang serba mendalam, mendasar, sistematis, terpadu, menyeluruh, dan universal mengenai konsep-konsep yang berkaitan dengan pendidikan atas dasar ajaran Islam.

\section{Fungsi filsafat Pendidikan islam}

Semestinya, bahwa setiap ilmu mempunyai kegunaan, menurut Omar Mohammad alToumy al-Syaibani misalnya mengemukakan tiga manfaat dari mempelajari filsafat pendidikan Islam, antaralain:

- Filsafat pendidikan itu dapat menolong para perancang pendidikan dan yang melaksanakannya dalam suatu negara untuk membentuk pemikiran sehat terhadap proses pendidikan;

\footnotetext{
${ }^{10}$ Nata, Filsafat Pendidikan, h. 15

11 Jalaludin dan Usman Said, Filsafat Pendidikan Islam: Konsep dan Perkembangan pemikirannya, (Jakarta:

RajaGrafindo Persada, 1994), h. 17.
} 
- Filsafat pendidikan dapat menjadi asas yang terbaik untuk penilaian pendidikan dalam arti menyeluruh; dan,

- Filsafat pendidikan Islam akan menolong dalam memberikan pendalaman pikiran bagi factor-faktor spiritual, kebudayaan, social, ekonomi dan politik di negara kita. ${ }^{12}$

Selain kegunaan yang tersebut di atas filsafat pendidikan Islam juga sebagai proses kritikkritik tentang metode- metode yang digunakan dalam proses pendidikan Islam, sekaligus memberikan arahan mendasar tentang bagaimana metode tersebut harus didayagunakan atau diciptakan agar efektif untuk mencapai tujuan. Lebih lanjut Muzayyin Arifin menyimpulkan bahwa filsafat pendidikan Islam harus bertugas dalam 3 dimensi, yakni:

- Memberikan landasan dan sekaligus mengarahkan kepada proses pelaksanaan pendidikan yang berdasarkan ajaran Islam;

- Melakukan kritik dan koreksi terhadap proses pelaksanaan tersebut; dan,

- Melakukan evaluasi terhadap metode dari proses pendidikan tersebut.

\section{Metode filsafat Pendidikan islam}

Prihal yang menyangkut metode pengembangan filsafat pendidikan Islam yang berhubungan erat dengan akselerasi penunjuk operasional dan teknis mengembangkan ilmu, yang semestinya didukung dengan penguasaan metode baik secara teoritis maupun praktis untuk tampil sebagai mujtahid atau pemikir dan keilmuan. Asumsi yang terbangun bahwasannya karya Omar Mohammad al-Toumy al-Syaibani (Falsafah Pendidikan Islam) yang tidak membahas metode tersebut. Apalagi mencukupkan sumber analisa hanya pada Plato dan Aritoteles-isme, padahal sefaham dengan para filosof Muslim (al-Kindi, al-Farabi, Ibn Sina, Ibn Rusyd dan yang sealiran dengannya). Kuat kemungkinannya ia terperangkap oleh missi dan strategi Barat yang mensupremasi dalam segala bidang.

Tentang metode pengembangan filsafat pendidikan Islam paling tidak bersumber pada 4 hal, yakni:

- Bahan tertulis (tekstual) al-Qur'an, al-Hadits dan pendapat pendahulu yang baik "salafus saleh"- bahan empiris, yakni dalam praktek kependidikan (kontekstual);

- Metode pencarian bahan; khusus untuk bahan dari al-Qur' an dan al-Hadits bisa melalui "Mu'jam al-Mufahros li Alfazh al-Karim" karya Muhammad Fuad Abd al-Baqi atau "Mu'jam al-Mufahros li Alfazh al-Hadits" karya Weinsink, dan bahan teoritis kepustakaan serta bahan teoritis lapangan;

- Metode pembahasan (penyajian); bisa dengan cara berpikir yang menganalisa faktafakta yang bersifat khusus terlebihdahulu selanjutnya dipakai untuk bahan penarikan kesimpulan yang bersifat umum (induktif); atau cara berpikir dengan menggunakan premis-premis dari fakta yang bersifat umum menuju ke arah yang bersifat khusus (deduksi); dan

\footnotetext{
${ }^{12}$ Al-Syaibani, Filsafat Pendidikan, h. 30.
} 
- Pendekatan (approach); pendekatan sangat diperlukan dalam sebuah analisa, yang bisa dikategorikan sebagai cara pandang (paradigm) yang akan digunakan untuk menjelaskan suatu fenomena.

Adapun yang dikembangkan dan dikaji masalah filsafat pendidikan Islam, maka pendekatan yang harus digunakan adalah perpaduan dari ketiga disiplin ilmu tersebut, yaitu: filsafat, ilmu pendidikan dan ilmu ke islam an. sebagaimana uraian terdahulu, yakni sebuah kajian tentang pendidikan yang radikal, logis, sistematis dan universal. Namun cirri-ciri dari berfikir filosofis ini dibatasi dengan ketentuan ajaran Islam. ${ }^{13}$

\section{E. Etika Dalam Filsafat Pendidikan}

Istilah etika (Ethict, dalam bahasa Inggris, atau ethica, dalam bahasa latin) secara etimologi berasal dari bahasa Yunani kuno, yaitu Ethos dalam bentuk tunggal mempunyai banyak arti: tempat tinggal yang biasa; padang rumput; kendang habitat; kebiasaan, adat; akhlak, watak; perasaan, sikap, cara berfikir .dalam bentuk jamak (ta etha) artinya adalah: adat kebiasaan. Dan arti terakhir inilah menjadi latar belakang bagi terbentuknya istilah "etika". Dalam istilah latin Ethos atau Ethikos selalu disebut dengan mos sehingga dari perkataan tersebut lahirlah moralitas atau yang sering diistilahkan dengan perkataan moral. Perkataan etika dalam pemakaian dipandang yang lebih luas dari perkataan moral, karena terkadang istilah moral sering dipergunakan hanya untuk menerapkan sikap lahiriah seseorang yang biasa dinilai dari wujud tingkah laku atau perbuatannya saja. Sedangkan etika dipandang selain menunjukkan sikap lahiriah seseorang juga meliputi kaidah-kaidah dan motif-motif perbuatan seseorang itu. ${ }^{14}$

Dalam ensiklopedia Pendidikan dijelaskan bahwa etika adalah filsafat tentang nilai, kesusilaan, tentang baik dan buruk, kecuali etika mempelajari nilai-nilai itu sendiri. Sedangkan di dalam kamus istilah Pendidikan Umum diungkapkan bahwa etika adalah bagian dari filsafat yang mengajarkan keseluruhan budi (baik dan buruk). ${ }^{15}$

Etika yang menjunjung tinggi tegaknya nilai-nilai kemanusiaan, kejujuran dan keadilan, sehingga menjadi sumber pijakan berperilaku yang benar. Etika (akhlak) berujung pada masalah perilaku tersebut, maka ketika ia melakukan sesuatu aktivitas dalam kehidupannya akan menunjukkan sikap sebagai cermin etika yang diberlakukannya.

Menurut Imam Ghazali, akhlak (etika) adalah keadaan yang bersifat batin di mana dari sana lahir perbuatan dengan tanpa berfikir dan tanpa dihitung resikonya (al khuluqu haitun

\footnotetext{
${ }^{13} \mathrm{https} / / /$ nurwahidabdulloh.wordpress.com/pengetahuan/filsafat/filsafat-pendidikan-islam/

${ }^{14}$ Suhrawadi K. Lubis. Op cit. HIm 1.

${ }^{15} \mathrm{Ibid}$. HIm. 2.
} 
rasikhotun tashduru'antha al afal bi suhulatin wa yusrin min ghoiri hajatin fikrin wa ruwaiyyatin). ${ }^{16}$ Sedangkan ilmu akhlak adalah ilmu yang berbicara tentang baik dan buruk dari suatu perbuatan. Ketika berbicara tentang nilai baik buruk maka munculah persoalan tentang konsep baik buruk. Etika juga berbicara tentang baik buruk, tetapi konsep baik buruk dalam etika bersumber kepada kebudayaan, sementara konsep baik buruk dalam ilmu akhlak bertumpu pada konsep wahyu, meskipun akal juga mempunyai kontribusi dalam menentukannya. ${ }^{17}$ Dari segi ini maka dalam etika dikenal ada etika barat, etika timur dan sebagainya, sementara al akhlaq al kaqimah tidak mengenai konsep regional, meskipun hal ini menimbulkan perbedaan pendapat, karena etika pun diartikan sebagai norma-norma kepantasan (etiket), yakni apa dalam Bahasa Arab disebut atau karma.

Tujuan etika dalam pandangan filsafat adalah "idealitas" yang sama bagi seluruh manusia di setiap waktu dan tempat dan dalam usaha mencapai tujuannya ini, etika mengalami kesukaran-kesukaran, oleh karena fisik dan anggapan orang terhadap perbuatan itu baik atau buruk adalah sangat relatif sekali, karena setiap orang atau golongan mempunyai konsepsi sendiri-sendiri. Selain itu etika menentukan ukuran tingkah laku yang baik dan yang buruk sejauh yang dapat diketahui oleh akal manusia. Pola hidup yang diajarkan Islam bahwa seluruh kegiatan peribadatan, hidup, dan mati adalah semata-mata dipersembahkan kepada Allah, maka tujuan terakhir dari segala tingkah laku manusia menurut pandangan etika Islam adalah keridhaan Allah.

\section{Dalam Pandangan Filsuf Islam tentang Etika}

Al-Farabi adalah penerus tradisi intelektual al-Kindi, tapi dengan kompetensi, kreativitas, kebebasan berpikir dan tingkat sofistikasi yang lebih tinggi lagi. Jika al-Kindi dipandang sebagai seorang filosof Muslim dalam arti kata yang sebenarnya, Al-Farabi disepakati sebagai peletak sesungguhnya dasar piramida studi falsafah dalam Islam yang sejak itu terus dibangun dengan tekun Ia termasyhur karena telah memperkenalkan doktrin "Harmonisasi pendapat Plato dan Aristoteles". ${ }^{18}$ Bahkan sejumlah kalangan menyebutnya sebagai "the second Master" atau Maha Guru Kedua setelah panutannya Aristoteles.Konsep etika yang ditawarkan al-Farabi dan menjadi salah satu hal penting dalam karya-karyanya,

\footnotetext{
${ }^{16}$ Abdul Wahid \& Moh. Muhibbind, Op.cit., HIm. 31.

17 Ibid. HIm 32.

${ }^{18}$ Sirajuddin Zar, Filsafat Islam: Filosof dan Filsafatnya ( Jakarta : Rajawali Pers, 2012), hlm. 67.
} 
berkaitan erat dengan pembicaraan tentang jiwa dan politik. Begitu juga erat kaitanya dengan persoalan etika ini adalah persoalan kebahagiaan. Di dalam kitab at-Tanbih fi Sabili al-Sa'adah dan Tanshil al-Sa'adah, al-Farabi menyebutkan bahwa kebahagiaan adalah pencapaian kesempurnaan akhir bagi manusia, al-Farabi juga menekankan empat jenis sifat utama yang harus menjadi perhatian untuk mencapai kebahagiaan di dunia dan di akhirat bagi bangsabangsa dan setiap warga negara.

Konsep etika Syekh Yūsuf bersumber dari al-Qur'an dan Sunnah yang merupakan sumber otoritas agama Islam. Selain itu, ia juga dipengaruhi oleh doktrin teologis, filosofis dan sufisme. Keempat hal tersebut sekaligus merupakan komponen dalam bangunan konsep etikanya, sehingga digolongkan dalam tipologi etika religius-berdasarkan batasan yang diberikan oleh Majid Fakhry. Dimensi aksiologis dari etika religius Syekh Yūsuf adalah pencapaian kebahagiaan, yaitu pengetahuan tertinggi tentang Tuhan, yang disebut dengan ma'rifah. Maka ia merumuskan cara untuk mencapai kebahagiaan itu berdasarkan refleksinya terhadap etos moral atau nilai-nilai ideal etis yang terdapat dalam sumber Islam. ${ }^{19}$

\section{KESIMPULAN}

Dari bebagai penjelasan mengenai materi konsep dasar filsafat Pendidikan islam maka selaku penulis artikel ini dapat memberikan pemahaman dalam wacana pengembangan intelektual bagi kami dari tim penulis secara khusus dan para pembaca secara umum, adapun kesimpulan yang dapat kami sajikan sebagai berikut:

1. pengertian filsafat pendidikan Islam menurut beberapa pakar ialah studi tentang pandangan filosofis dan sistem dari aliran filsafat terhadap masalah kependidikan yang harus didasarkan pada ajaran Islam.

2. ruang lingkup filsafat pendidikan Islam menurut berbagai pakar piala segala aspek yang menjangkau permasalahan kehidupan manusia dan alam semesta.

3. fungsi filsafat Islam pertama membantu para pakar pendidikan untuk membentuk pemikiran sehat terhadap proses pendidikan kemudian menjadi asas untuk penilaian Pendidikan.

\footnotetext{
${ }^{19}$ Sainuddin, Ibnu Hajar, and Ismail Suardi Wekke. "Syekh Yusuf Al-Makassari: Pandangan Etika dan Filsafat." (2020), hlm. 1. \& Mustari, Belajar Etika Kepada Syekh Yusuf Al-Makassari,(2020).hlm.145
} 
4. metode filsafat pendidikan Islam salah satu metode filsafat pendidikan Islam ialah metode pencarian bahan kemudian metode pembahasan atau penyajian bahan yang telah tentukan.

5. Konsep etika religius Syekh Yūsuf dipandang masih memiliki relevansi dengan konteks sosio-religius di Indonesia, khususnya dengan fenomena kekerasan atas nama agama. Hal ini karena etika religius Syekh Yūsuf bertumpu pada kesadaran bahwa segala yang ada adalah Mazahir Tuhan, sehingga berbuat baik kepada makhluk sama halnya dengan berbuat baik kepada-Nya. Maka dengan kesadaran tersebut seseorang akan selalu memperlakukan sesamanya dengan baik dan pantas, serta tidak mudah mengambil jalan kekerasan apalagi dengan mengatasnamakan agama.

\section{DAFTAR PUSTAKA}

Hidayat, Rahmat \& Nasution, H.S. (2016) Filsafat Pendidikan Islam Membangun Konsep Dasar Pendidikan Islam. Medan: LPPPI

Nata, Abuddin, Filsafat Pendidikan Islam, Gaya Media Pratama, Jakarta, 2005

Nata, Abuddin, Pemikiran Pendidikan Islam dan Barat, RajaGragindo, Jakarta, 2013

Tafsir, Ahmad, Ilmu Pendidikan Islami, Remaja Rosda Karya, Bandung, 2013

Tafsir, Ahmad, Filsafat Pendidikan Islami, Remaja Rosda Karya, Bandung, 2014

Tafsir, Ahmad, Filsafat Ilmu, Remaja Rosda Karya, bandung, 2013

Arifin, HM, Filsafat Pendidikan Islam, Bumi Aksara, 2000

Rahmat Hidayat.2016. Manajemen Pendidikan Islam. Medan: LPPPI

Sainuddin, Ibnu Hajar, and Ismail Suardi Wekke. "Syekh Yusuf Al-Makassari: Pandangan Etika dan Filsafat." (2020).

Taufik, M. (2016). Etika dalam Perspektif Filsafat Islam. Etika: Teori, Praktik, dan Perspektif, edited by Zuhri, 35-64.

Dewantara, Agustinus. "Filsafat Moral (Pergumulan Etis Keseharian Hidup Manusia)." (2017).

Bertens, K. (1993). Etika K. Bertens (Vol. 21). Gramedia Pustaka Utama.

Sainuddin, Ibnu Hajar, Muhammad Arsyam, and Ismail Suardi Wekke. "Syekh Yusuf Al- Makassari; Pengembangan Masyarakat Islam.” (2020) 
